\title{
COMPARISON OF METHODS FOR EVALUATING UPPER LIMB STRENGTH BY HAND-HELD DYNAMOMETRY
}

\author{
COMPARAÇÃO ENTRE MÉTODOS NA AVALIAÇÃO DEDINAMOMETRIA HAND-HELD PARA MÚSCULOS DOS
} MEMBROS SUPERIORES

\author{
COMPARACIÓN ENTRE MÉTODOS EN LA EVALUACIÓN DE DINAMOMETRÍA HAND-HELD PARA MÚSCULOS \\ DE LOSMIEMBROS SUPERIORES
}

\begin{abstract}
Balbino Rivail Ventura Nepomuceno Júnior 1,2 (ID

(Physiotherapist)

Manoela Porto dos Santos

Menezes ${ }^{2}$ (ID)

(Physiotherapist)

Kamilla Ribeiro Bastos dos Santos² (iD (Physiotherapist)

Mansueto Gomes Neto² (ID

(Physiotherapist)

1. Universidade Federal da Bahia,

Postgraduate Program in Interactive Processes of Organs and Systems,

Salvador, BA, Brazil.

2. Universidade Federal da Bahia,

Instituto de Ciências da saúde,

Physiotherapy Research Group,

Salvador, BA, Brazil.

3. Pavilhão de Aulas do Canela

$(\mathrm{PAC})$, Universidade Federal da

Bahia, Salvador, BA, Brazil.
\end{abstract}

\section{Correspondence:}

Balbino Rivail Ventura Nepomuceno Júnior. Av. Centenário, 2411, Sl 403, Chame Chame, Salvador, BA, Brazil. 41157-151.

balbino.nepomuceno@gmail.com

\begin{abstract}
Introduction: The upper limbs are segments of the human body responsible for primary activities of daily life, and the muscles are essential structures for performing these activities. There have been few studies on intra- and inter-examiner reliability of the hand-held dynamometer (HHD) in healthy subjects, and none have been published that compare dynamometric evaluation methods in the main muscles in this segment. Objective: Evaluate intra-examiner and inter-examiner assessment reliability of the hand-held dynamometry of upper limb muscles in healthy individuals, as well as comparing the assessment reliability between fixed and non-fixed methods. Methods: Healthy subjects aged over 18 years were recruited for the study. The isometric contraction for ten muscle groups of the dominant upper limb was tested. For the fixed method, we used a system of suction cups, connected to the HHD by an inelastic belt. For the non-fixed method, the examiner supported the device by hand. The isometric contraction was sustained for three seconds. Each measurement was repeated three times, considering the highest value obtained. The reliability was calculated using the intraclass correlation coefficient (ICC). The dispersion between measurements was expressed by a Bland-Altman plot. Results: The sample consisted of 25 volunteers, all right-handed. The intra-examiner ICC was 0.89-0.99 for the non-fixed method, and 0.43 to 0.85 for the fixed method. Inter-examiner reliability showed equivalent behavior. This study showed that evaluation of upper limb muscle strength using an isometric dynamometer has excellent intra-examiner and inter-examiner reliability. The supine position was chosen due to the need to propose a feasible protocol for clinical practice that could be replicated for the majority of publics and in different environments. The non-fixed method showed better reliability overall, demonstrating the feasibility of this tool without the need for adaptations, additional devices, or increased operating costs for this evaluation. Conclusion: Comparison between the fixed and non-fixed HHD methods demonstrated superiority of the non-fixed method in terms of reliability. Level of evidence ll; Investigation of a diagnostic exam - Development of diagnostic criteria with consecutive patients.
\end{abstract}

Keywords: Muscle strength dynamometer; Muscular contraction; Muscle strength; Diagnosis; Data accuracy.

\section{RESUMO}

Introdução: Os membros superiores são segmentos do corpo humano responsáveis por atividades primordiais do nosso cotidiano, e os músculos são estruturas imprescindiveis para isso. Ainda são escassos na literatura os estudos sobre a confiabilidade intra e interexaminadores da dinamometria Hand-Held em indivíduos saudáveis, sendo inédita a comparação entre os métodos de avaliação da dinamometria nos principais músculos desse segmento. Objetivo: Avaliar a confiabilidade da avaliação intraexaminador e interexaminador da dinamometria manual de músculos do membro superior rem individuos saudáveis, bem como comparar a confiabilidade da avaliação entre métodos fixos e não fixos. Métodos: Foram recrutados indivíduos saudáveis, maiores de 18 anos. A contração isométrica para dez grupos musculares do membro superior dominante foi testada. Para o método fixado, foi empregado um sistema deventosas conectado ao Dinamomêtro Hand-Held (DHH) por um cinto inelástico. No método não fixado, o examinador apoiou o aparelho com a mão. A contração isométrica foi sustentada por três segundos. Cada medida foi repetida três vezes, considerando o maior valor obtido. A confiabilidade foi calculada através do coeficiente de correlação intraclasse (CCI). A dispersão entre as medidas foi expressa pelo diagrama de Bland-Altman. Resultados: A amostra foi composta por 25 voluntários, todos destros. O coeficiente de correlação intraclasse (CCI) dos intraexaminadores para método não fixado foi de 0,89 a 0,99e, para o método fixado, situou-se entre 0,43 e 0,85. A confiabilidade interexaminadores teve comportamento equivalente. O presente estudo demonstrou que a avaliação da força dos músculos dos MMSS com dinamômetro isométrico apresenta excelente confiabilidade tanto intra como interexaminadores. A escolha do posicionamento em supino vem da necessidade de propor um protocolo factível na prática clínica, replicável para a maioria dos públicos eem ambientes diversos. O fato de o método não fixado demonstrar maior confiabilidade, em geral, expõe a viabilidade do uso dessa ferramenta sem necessidade de adaptações, dispositivos adicionais ou aumento do custo operacional nessa avaliação. Conclusão: A comparação entre os métodos fixados e os não fixados da dinamometria Hand-Held demonstrou superioridade do método não fixado quanto à confiabilidade. Nível de evidência ll; Estudos diagnósticos - Investigação de um exame para diagnóstico - Desenvolvimento de critérios diagnósticos com pacientes consecutivos.

Descritores: Dinamômetro de força muscular; Contração muscular; Força muscular; Diagnóstico; Confiabilidade dos dados. 


\section{RESUMEN}

Introducción: Los miembros superiores son segmentos del cuerpo humano responsables de las actividades primordiales de nuestro cotidiano, y los músculos son estructuras imprescindibles para eso. Aún son escasos los estudios sobre la confiabilidad intra e interexaminadores de la dinamometría Hand-Held en individuos saludables, siendo inédita la comparación entre los métodos de evaluación de la dinamometría en los músculos principales de ese segmento. Objetivos: Evaluar la confiabilidad de la evaluación intraexaminador e interexaminador de la dinamometría manual de músculos del miembro superior en individuos saludables, bien como comparar la confiabilidad der la evaluación entre métodos fijos y no fijos. Métodos: Se reclutaron individuos saludables, mayores de 18 años. Se probó la contracción isométrica para diez grupos musculares del miembro superior dominante. Para el método fijado, se utilizó un sistema de ventosas, conectado al Dinamómetro Hand-Held (DHH) a través de un cinturón inelástico. En el método no fijado, el examinador apoyó el aparato con la mano. La contracción isométrica fue sustentada por tres segundos. Cada medición fue repetida tres veces, considerando el valor más alto obtenido. La confiabilidad fue calculada a través del coeficiente de correlación intraclase (CCI). La dispersión entre las mediciones se expresó por el diagrama de Bland-Altman. Resultados: La muestra fue compuesta por 25 voluntarios, todos diestros. El coeficiente de correlación intraclase (CCI) de los intraexaminadores para método no fijado fue de 0,89 a 0,99 y, para el método fijado fue entre 0,43 y 0,85. La confiabilidad intraexaminadores tuvo comportamiento equivalente. El presente estudio demostró que la evaluación de la fuerza de los músculos de los MMSS con un dinamómetro isométrico presenta excelente confiabilidad tanto intra como interexaminadores. La elección del posicionamiento en supino viene de la necesidad de proponer un protocolo factible en la práctica clínica, replicable para la mayoría de los públicos y en ambientes diversos. El hecho de que el método no fijado demuestre mayor confiabilidad, en general, expone la viabilidad del uso de esa herramienta sin necesidad de adaptaciones, dispositivos adicionales o aumento del costo operacional, en esa evaluación. Conclusión: La comparación entre los métodos fijados y no fijados de la dinamometría Hand-Held demostró superioridad del método no fijado cuanto a la confiabilidad. Nivel de evidencia Il; Estudios diagnósticos - Investigación de un examen para diagnóstico-Desarrollo de criterios diagnósticos con pacientes consecutivos.

Descriptores: Dinamómetro de fuerza muscular; Contracción muscular; Fuerza muscular; Diagnóstico; Exactitud de los datos.

\section{INTRODUCTION}

Movement production is directly related to the ability of the muscle to produce tensile strength, which, in turn, is influenced by its cross-sectional area, neural activation, bioenergetic reserve, and length and capacities of stretching and shortening of its fibers. ${ }^{1,2}$ It is known that muscle strength deficiency has a negative impact on functional performance and autonomy, making it difficult to perform basic and instrumental activities of daily living (ADL). ${ }^{2-4}$

The upper limbs (UL) are segments of the human body responsible for allowing essential activities of our daily life, such as eating, performing work activities, hygiene, gestural communication and effective interaction with the various technological devices. Much more than functions, the upper limbs, having adequate strength, coordination and precision of movements, allow the human species to perform multiple activities, of different possibilities and complexities, and each individual to be unique in their expressions and social participation., ${ }^{2,5}$

The graduation of muscle strength is an essential tool to adequate physical training prescription, guidance on the diagnosis of muscle dysfunctions and disabilities in sick individuals, and also regarding guidance on preventive programs for injuries arising from imbalances between antagonistic muscle chains. However, it is worth mentioning that graduating a specific muscle group strength is as important as guaranteeing the veracity and reliability of this measurement. .-10 $^{-10}$

The Hand-Held Dynamometer (HHD) is a portable device, capable of grading muscle strength through sustained maximum isometric contraction. Its size and weight enable easy handling during evaluation, which makes its use reproducible. Such characteristics allow it to be used in the most diverse environments and audiences. However, there is still little evidence of the reliability of this instrument, which uses simple and feasible protocols for clinical practice that addresses different muscles of UL., 811,12

This research aimed to evaluate intra-examiner and inter-examiner assessment reliability of the hand-held dynamometry of upper limb muscles in healthy individuals, as well as comparing the assessment reliability between fixed and non-fixed methods.

\section{MATERIALS AND METHODS}

\section{Participants}

Healthy individuals were recruited by direct call, via text message, or social network. Before recruitment, a sample calculation was performed respecting $10 \%$ of variation between measurements, 0.05 a and $80 \%$ power, and 25 participants were included in the research.

Inclusion was for individuals of both sexes above 18 years of age, who voluntarily agreed in participating in the research and signed the informed consent form. Individuals were excluded when presented acute osteomyoarticular disease or symptoms; reduced functional range of motion (ROM): ${ }^{13}$ severe heart disease or neuromuscular diseases, and cognitive limitation that restricted the understanding of motor commands during assessment.

\section{Randomization}

In order to eliminate bias, the order of assessment between fixed and non-fixed methods was randomized for all patients. Through simple randomization, part of the participants started the Hand-Held dynamometry assessment using the fixed method and the others using the non-fixed method.

\section{Instruments}

Muscle strength assessment was performed using a previously calibrated Lafayette Hand-Held Dynamometer, model 01165 (Lafayette, Sagamore, USA). An ISP goniometer (São Paulo, BR) was also used to properly mark the articular position of the segments for each evaluated movement. ${ }^{14}$ All patients had the proximal segment (trunk, arm or forearm) stabilized by using a inelastic belt in order to null the effect of synergistic muscle chains and their irradiation of strength. ${ }^{15}$ 


\section{Procedures}

The assessment was carried out in a reserved and appropriate place. Before the test was performed, the examiners were trained to carry out the assessment according to the current protocol. In this protocol, isometric contraction was tested for 10 muscle groups of the dominant upper limb. The volunteers were guided, trained and warmed up for each movement before the measurement.

For the fixed method, a system of suction cups was used, adhered to rigid surfaces, connected to the HHD through a Mulligan-type inelastic belt .${ }^{16}$ In the non-fixed method, the examiner supported the device with one hand, in a vector contrary to the movement, stabilizing with the contralateral hand the segment proximal to the joint of the evaluated movement. ${ }^{14,17-20}$

The isometric contraction was sustained for three seconds, guided by an audible beep from the equipment. Each movement was performed with three repetitions, considering the highest of the three values, always with the examiner's incentive: Keep going! Keep going! Keep going! The dynamometer was positioned in the distal region of the forearm, always five centimeters from the radial styloid process. ${ }^{21}$ Muscle recovery time between the tests was respected for all measurements. If there was visible compensation for synergistic muscles in any of the movements, the volunteer would be guided and the measurement repeated.

HHD positions were expressed in Table 1.19

\section{Reliability}

For intra-examiner reliability, the test-retest Hand-Held Dynamometry was measured for the same examiner. For inter-examiner reliability, the Hand-Held dynamometry was measured for two independent examiners. Between each phase of the test, a minimum 30-minute rest time was respected, excluding possibility of confusion due to fatigue.

\section{Ethical aspects}

The research was approved by the Research Ethics Committee of the Institute of Health Sciences of the Federal University of Bahia, under no. 1537948 , and it is in line with the Declaration of Helsinki. All volunteers signed the Informed Consent Form.

Table 1. HHD assessment positions.

\begin{tabular}{|c|c|c|c|}
\hline Joint & Movement & Body position & HHD \\
\hline \multirow[t]{6}{*}{ Shoulder } & Flexion $^{17}$ & $\begin{array}{l}\text { Supine, shoulder } 90^{\circ} \text { of flexion, elbow } \\
\text { and wrists } 0^{\circ} \text {, forearm pronated. }\end{array}$ & $\begin{array}{l}\text { Posterior } \\
\text { forearm }\end{array}$ \\
\hline & Extension ${ }^{17}$ & $\begin{array}{l}\text { Supine, shoulder } 90^{\circ} \text { of flexion, elbow } \\
\text { and wrists } 0^{\circ} \text {, forearm pronated. }\end{array}$ & $\begin{array}{l}\text { Anterior } \\
\text { forearm }\end{array}$ \\
\hline & Abduction $^{14,18}$ & $\begin{array}{l}\text { Supine, } 45^{\circ} \text { abduction shoulder, } \\
\text { elbow and wrists } 0^{\circ} \text {, forearm } \\
\text { in intermediate position. }\end{array}$ & $\begin{array}{l}\text { Posterior } \\
\text { forearm }\end{array}$ \\
\hline & Adduction ${ }^{14,18}$ & $\begin{array}{l}\text { Supine, } 45^{\circ} \text { abduction shoulder, } \\
\text { elbow and wrists } 0^{\circ} \text {, forearm } \\
\text { in intermediate position. }\end{array}$ & $\begin{array}{l}\text { Anterior } \\
\text { forearm }\end{array}$ \\
\hline & $\begin{array}{l}\text { Internal } \\
\text { rotation }\end{array}$ & $\begin{array}{l}\text { Supine, abduction shoulder } 90^{\circ}, \\
\text { flexion elbow } 90^{\circ} \text { and wrists } \\
0^{\circ} \text {, supinated forearm. }\end{array}$ & $\begin{array}{l}\text { Anterior } \\
\text { forearm }\end{array}$ \\
\hline & $\begin{array}{l}\text { External } \\
\text { rotation }^{14}\end{array}$ & $\begin{array}{l}\text { Supine, abduction shoulder } 90^{\circ} \text {, } \\
\text { flexion elbow } 90^{\circ} \text { and wrists } \\
0^{\circ} \text {, supinated forearm. }\end{array}$ & $\begin{array}{l}\text { Posterior to } \\
\text { the forearm }\end{array}$ \\
\hline \multirow[t]{2}{*}{ Elbow } & Flexion $^{19}$ & $\begin{array}{l}\text { Supine, shoulder and wrist } 0^{\circ} \text {, elbow } \\
90^{\circ} \text { of flexion, supinated forearm. }\end{array}$ & $\begin{array}{l}\text { Anterior } \\
\text { forearm }\end{array}$ \\
\hline & Extension $^{19}$ & $\begin{array}{l}\text { Supine, shoulder and wrist } 0^{\circ} \text {, elbow } \\
90^{\circ} \text { of flexion, forearm pronated. }\end{array}$ & $\begin{array}{l}\text { Anterior } \\
\text { forearm }\end{array}$ \\
\hline \multirow[t]{2}{*}{ Wrist } & Flexion $^{20}$ & $\begin{array}{l}\text { Supine, abduction shoulder } 30^{\circ} \text {, elbow } \\
\text { and wrist } 0^{\circ} \text {, supinated forearm and } \\
\text { supported on stretcher with wrist out. }\end{array}$ & $\begin{array}{l}\text { Anterior carpal } \\
\text { surface }\end{array}$ \\
\hline & Extension ${ }^{20}$ & $\begin{array}{l}\text { Supine, abduction shoulder } 30^{\circ} \text {, elbow } \\
\text { and wrist } 0^{\circ} \text {, forearm pronated and } \\
\text { supported on stretcher with wrist out. }\end{array}$ & $\begin{array}{c}\text { Anterior carpal } \\
\text { surface }\end{array}$ \\
\hline
\end{tabular}

\section{Statistical Method}

Tabulation and data analysis were performed with SPSS (Statistical Package for the Social Sciences) software, version 21.0, using descriptive statistics, and data presented in tables and graphs. Qualitative data were exposed in absolute and relative frequency; quantitative data were expressed as mean and standard deviation. Student's t test was used to evaluate the difference between mean peak torque obtained between the methods, considering a statistically significant value of $p<0.05$

Reliability was calculated using the intraclass correlation coefficient (ICC) and was categorized using the classification proposed by Weir (2005):22 excellent for values between 1.0 and 0.81 ; very good from 0.80 to 0.61 ; good from 0.60 to 0.41 ; reasonable from 0.40 to 0.21 , and poor from 0.20 to 0.00 . The dispersion between intra and inter-examiner measurements was expressed using the Bland-Altman plot for non-fixed and fixed measurements.

\section{RESULTS}

The sample consisted of 25 volunteers, and their anthropometric characteristics are shown in Table 2. It was observed that, in general, the peak torque in the non-fixed method was greater than in the fixed method. However, no significant difference was found between means, except for elbow flexion ( $p=0.049)$, as shown in Table 3. The Bland-Altman graph for intra-examiner reliability is presented in Figure 1.

Table 4 reflects the intra-examiner reliability for non-fixed and fixed groups, with all ICC categorized as excellent. The Bland-Altman graph for inter-examiner reliability is presented in Figure 2, ratifying the difference in reliability between groups for the highest ICC. The inter-examiner reliability is shown in Table 5, observing that the non-fixed method maintained an excellent categorization, and the fixed method presented varied reliability, between excellent and reasonable, for the 10 joints of the upper limbs evaluated.

\section{DISCUSSION}

This study demonstrated that the strength assessment of upper limb muscles with an isometric dynamometer presents excellent reliability for both intra-examiner and inter-examiner assessments. This finding seems to relate to the structured protocol, as well as to the constant training of the collection group, composed of physical therapists and experts in anatomy and biomechanics. The study by Saccol et al. ${ }^{21}$ also evaluated the reliability of the Hand-Held dynamometry of the internal and external rotators of the shoulder, in supine position, similarly to which was adopted in the protocol of this study and in sitting position, with fixation in a rigid device. The results found reflect levels of reliability

Table 2. Anthropometric characteristics of the sample $(n=25)$

\begin{tabular}{|c|c|c|}
\hline & $\mathrm{n}(\%)$ & Mean (SD) \\
\hline Gender (female) & $15(60)$ & \\
\hline Age (years) & & $33.1(13.4)$ \\
\hline Race Brown & $13(52)$ & \\
\hline White & $7(28)$ & \\
\hline Black & $5(20)$ & \\
\hline Weight (kg) & & $72.6(18.3)$ \\
\hline Height (m) & & $1.7(0.1)$ \\
\hline $\mathrm{BMI}$ & & $24.9(5.0)$ \\
\hline Dominance (right-handed) & $25(100)$ & \\
\hline IPAQ: Sedentary & $9(36)$ & \\
\hline Active & $7(28)$ & \\
\hline Irregularly active & $4(16)$ & \\
\hline Very active & $3(12)$ & \\
\hline Other & $2(08)$ & \\
\hline Physical activity frequency (days) & & $3.5(1.5)$ \\
\hline
\end{tabular}


Table 3. Mean and standard deviation of the peak torque of the muscle groups evaluated $(n=25)$.

\begin{tabular}{|c|c|c|c|c|c|c|c|}
\hline \multirow[b]{2}{*}{ Joint } & \multirow[b]{2}{*}{ Movement } & \multicolumn{3}{|c|}{ Non-fixed } & \multicolumn{3}{|c|}{ Fixed } \\
\hline & & ICC & $95 \% \mathrm{Cl}$ & Reliability* & ICC & $95 \% \mathrm{Cl}$ & Reliability* \\
\hline \multirow[t]{6}{*}{ Shoulder } & Flexion & 0.99 & {$[0.97-0.99]$} & Excellent & 0.64 & {$[0.18-0.92]$} & Very good \\
\hline & Extension & 0.93 & [0.80- 0.98] & Excellent & 0.56 & {$[0.17-0.91]$} & Good \\
\hline & Abduction & 0.98 & {$[0.93-0.99]$} & Excellent & 0.76 & {$[0.20-0.95]$} & Very good \\
\hline & Adduction & 0.98 & [0.94- 0.99] & Excellent & 0.85 & {$[0.29-0.97]$} & Excellent \\
\hline & Internal rotation & 0.96 & {$[0.87-0.98]$} & Excellent & 0.95 & [0.75-099] & Excellent \\
\hline & External rotation & 0.98 & {$[0.90-0.99]$} & Excellent & 0.82 & {$[0.12-0.96]$} & Excellent \\
\hline \multirow[t]{2}{*}{ Elbow } & Flexion & 0.97 & {$[0.93-0.99]$} & Excellent & 0.43 & {$[0.04-0.88]$} & Good \\
\hline & Extension & 0.99 & {$[0.98-0.99]$} & Excellent & 0.84 & {$[0.20-0.96]$} & Excellent \\
\hline \multirow[t]{2}{*}{ Wrist } & Flexion & 0.91 & {$[0.75-0.97]$} & Excellent & 0.52 & {$[0.36-0.90]$} & Good \\
\hline & Extension & 0.89 & {$[0.67-0.96]$} & Excellent & 0.71 & {$[0.43-0.94]$} & Very good \\
\hline
\end{tabular}

that vary between good and very good in the classification adopted by Weir. ${ }^{22}$ In this study, the fixed method found levels of reliability similar to those of the study by Saccol et al. ${ }^{21}$ In turn, the non-fixed method demonstrated greater reliability than that of the mentioned study. The justification for better results with a similar protocol can be attributed to the fact that Saccol et al..$^{21}$ use examiners without clinical experience, and, in this work, the volunteers were evaluated by experienced and previously trained examiners.

The comparison between fixed and non-fixed methods demonstrated the superiority of the non-fixed method regarding both intra-examiner and inter-examiner assessments. This finding is similar to that found by Davis et al. ${ }^{15}$ in a study that assessed Hand-Held dynamometry reliability for plantar flexion. Regarding the fact that higher ICC were found for the non-fixed method, in comparison with the fixed method, it is worth mentioning that both methods showed excellent reliability. Greater reliability results for the non-fixed method seem to diverge from the trend shown in the study by Almeida et al. ${ }_{1}^{16}$ which evaluated the rectus femoris of 70 participants before the reconstruction of the anterior cruciate ligament, and demonstrated an intra-examiner reliability of 0.98 [0.98-0.99] with the fixed method. It is important to mention that the study did not express inter-examiner reliability, nor did it compare the non-fixed method.

For $U L$, there is a scarcity of studies comparing the reliability between fixed and non-fixed methods for most movements in this segment, as seen in a recent systematic review. ${ }^{5}$ This study was based on the results found for lower limbs and on fundamentals of biomechanics according to which force vectors with opposite directions would null each other in the isometric movement, as long as there is no visible angular movement. This hypothesis was reinforced by the superiority found in the non-fixed method compared to the fixed method. The difference between the mean peak torque was not significant between the methods, with the exception of dynamometry for elbow flexion:

$$
171.4(26.1) \times 110.2 \text { (32.8), with } p=0.049 \text {. }
$$

The choice of supine position is due to the need to propose a feasible protocol in clinical practice, replicable for most audiences and in different environments, making the measurement of UL muscle strength more accessible and explored. This study assesses the reliability of this instrument and the protocol for evaluating the main muscles of UL. This initiative to propose the assessment of reliability for 10 of the main muscles of UL is innovative. In view of the satisfactory results of inter and intra-examiner reliability, the results suggest that portable isometric dynamometry is a potential tool for the assessment of healthy individuals by previously trained examiners. The margin of this impression, in the review of the European consensus on the definition and diagnosis of Sarcopenia, ${ }^{1}$ published in 2018, still demonstrates limitations in tests and methods to quantify the magnitude of strength loss, and it is restricted to the assessment of hand grip and chair stand test. This study focuses on the possibility that this tool could be a viable alternative for a more extensive and comprehensive diagnosis of UL muscle strength.

In a study with swimmers, Awatani et al. ${ }^{23}$ measured the reliability of HHD as a non-fixed method for internal and external rotators of the shoulder in swimmers without acute pain. In the mentioned study, the authors found, for internal rotators, an intra-examiner reliability of 0.94 [0.81-0.98], lower than the inter-examiner reliability of 0.96 of this study - 0.96 [0.870.99] -, higher than the 0.93 reliability in this study. All measures, however, are within the "excellent" reliability classification proposed by Weir. ${ }^{22}$ For external rotation, all reliability measurements in this study were superior to those found by Awatani et al. ${ }^{23}$ Hand-Held dynamometry excellence for shoulder is reinforced in the study by Candogan et al. ${ }^{24}$ who evaluated, with the non-fixed method, several shoulder movements in patients with ongoing inflammatory process and found reliability, expressed by ICC, between 0.85 and 0.99 , for test and retest and between examiners.

Dowman et al. ${ }^{25}$ evaluated, with the non-fixed method, the reliability of HHD for elbow flexors and knee extensors in patients with interstitial lung disease. For elbow flexors, the assessment protocol was similar to that of this study. As a result, intra-examiner reliability of 0.98 was found, with 95\% Cl (0.96-0.99), similar to that found in this study, with ICC of 0.97. Regarding inter-examiner reliability, Dowman et al. ${ }^{25}$ found values higher than the ones in this study, that is, 0.95 (0.88-0.99) against 0.83 in this study, with an excellent reliability rating for both studies, which reinforces the importance of this measurement instrument for elbows and in diverse populations.

Reliability for wrist flexion and extension using the fixed method was considered excellent for test and retest, and also for comparison of measurements between examiners in the non-fixed method. In turn, ICC of the fixed method oscillated between good and reasonable for wrist flexion, and between very good and excellent for wrist extension. Similar behavior was found in the study by Rheault et al., ${ }^{20}$ who assessed the intra-examiner reliability of the Hand-Held dynamometry during wrist flexion and extension in twenty volunteers. In the abovementioned study, the assessment protocol was similar to that used in this study, but it did not use verbal stimulus during the measurement and did not stabilize the distal segment to control compensations. However, Rheault et al. ${ }^{20}$ found ICC of 0.91 for wrist extensors and ICC of 0.85 for wrist flexors. Such results were equivalent to the intra-examiner reliability found in this study.

This study is a pioneer in assessing the reliability of 10 muscles of UL, demonstrating its clinical importance. The fact that the non-fixed method generally presents greater reliability exposes the feasibility of using this tool without the need for adaptations, additional devices or increased operational cost in the assessment. Such fact may explain the increased use of this tool in gyms, clubs and performance clinics. However, there is a need for further studies on using Hand-Held dynamometry in young populations, as well as the validation of this method and delimitation of 


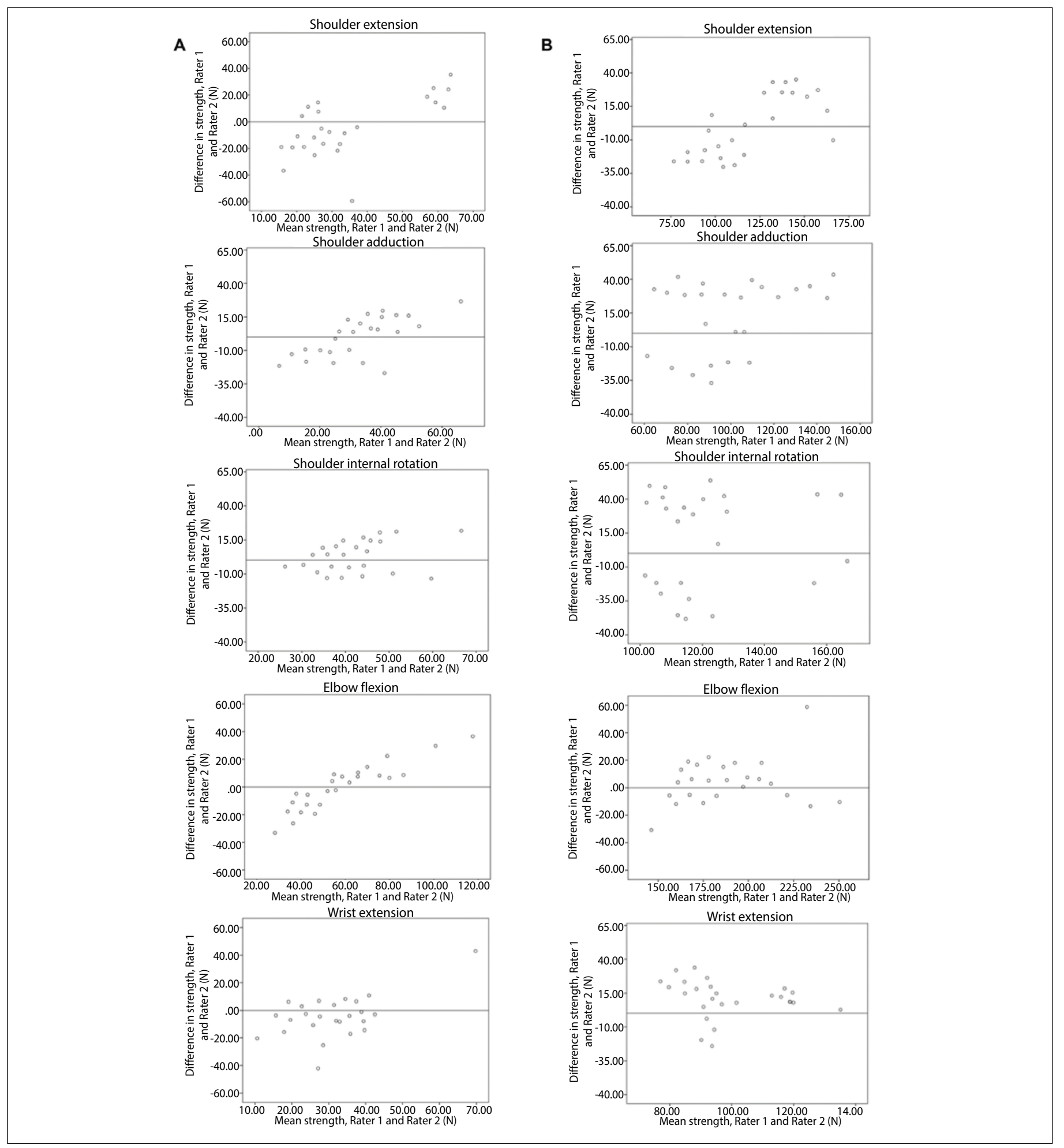

Figure 1. Bland Altman graphs show intra-examiner reliability between non-fixed (A) and fixed (B) methods.

Table 4. Dynamometry intra-examiner reliability with non-fixed and fixed methods $(n=25)$.

\begin{tabular}{c|c|c|c|c|c|c|c}
\hline & & \multicolumn{3}{|c|}{ Non-fixed } & \multicolumn{3}{c}{ Fixed } \\
\hline Joint & Movement & Test & Retest & Examiner2 & Test & Retest & Examiner2 \\
\hline Shoulder & Flexion & $96.0(22.6)$ & $97.3(23.2)$ & $81.8(11.8)$ & $71.5(15.5)$ & $61.0(20.0)$ & $90.7(17.2)$ \\
\hline & Extension & $112.1(25.1)$ & $106(24.8)$ & $96.9(17.0)$ & $76.5(22.0)$ & $82.4(25.3)$ & $102.1(16.8)$ \\
\hline & Abduction & $92.3(15.1)$ & $89.1(19.3)$ & $79.8(20.2)$ & $74.4(16.6)$ & $68.8(14.0)$ & $81.2(14.9)$ \\
\hline & Adduction & $115.7(13.8)$ & $108.9(28.1)$ & $101.5(27.7)$ & $69.0(20.5)$ & $75.9(16.4)$ & $96.7(12.0)$ \\
\hline & Internal rotation & $112.5(21.4)$ & $114.7(18.5)$ & $104.9(29.0)$ & $95.2(17.4)$ & $106.0(18.6)$ & $75.6(21.4)$ \\
\hline & External rotation & $115.5(22.5)$ & $115.9(25.6)$ & $114.1(27.7)$ & $94.5(26.3)$ & $91.1(24.1)$ & $71.6(17.2)$ \\
\hline & Flexion & $171.4(26.1)$ & $166.6(24.5)$ & $147.2(25.4)$ & $110.2(32.8)$ & $132.4(28.0)$ & $125.9(28.0)$ \\
\hline & Extension & $125.8(26.8)$ & $124.6(25.3)$ & $103.1(19.2)$ & $107.1(27.2)$ & $96.7(30.7)$ & $117.8(37.8)$ \\
\hline & Flexion & $72.4(13.8)$ & $69.1(18.3)$ & $96.5(13.9)$ & $68.6(15.2)$ & $84.8(15.2)$ & $92.6(17.9)$ \\
\hline
\end{tabular}




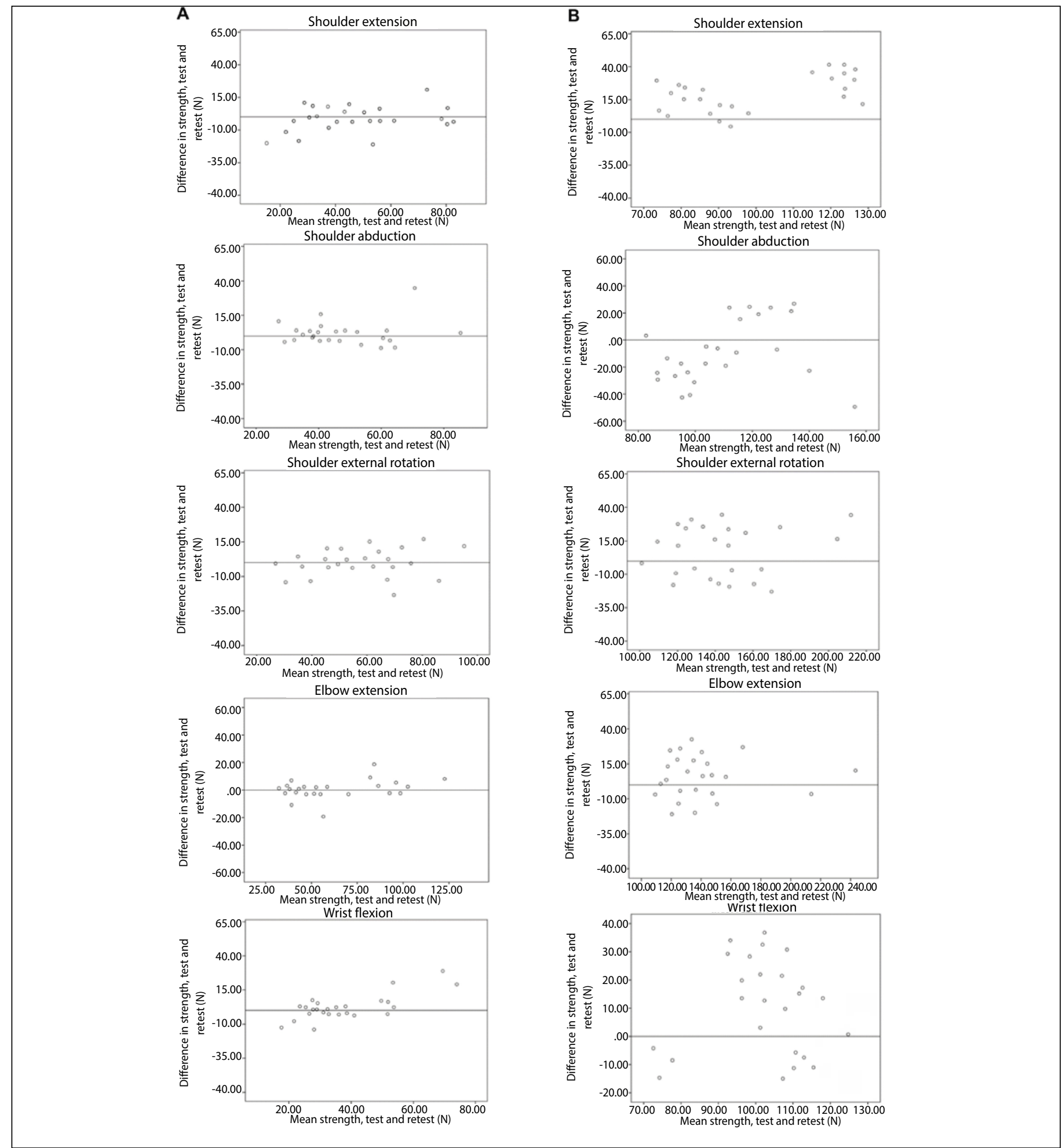

Figure 2. Bland Altman graphs show inter-examiner reliability between non-fixed (A) and fixed (B) methods.

Table 5. Dynamometry inter-examiner reliability between non-fixed and fixed methods ( $n=25$ ).

\begin{tabular}{c|c|c|c|c|c|c|c}
\hline & & \multicolumn{2}{|c}{ Non-fixed } & \multicolumn{2}{c}{ Fixed } \\
\hline Joint & Movement & ICC & $\mathbf{9 5 \% C l}$ & Reliability & ICC & 95\%Cl & Reliability* \\
\hline Shoulder & Flexion & 0.85 & {$[0.36-0.97]$} & Excellent & 0.71 & {$[0.42-0.94]$} & Very good \\
\hline & Extension & 0.82 & {$[0.19-0.96]$} & Excellent & 0.62 & {$[0.08-0.92]$} & Very good \\
\hline & Abduction & 0.90 & {$[0.56-0.98]$} & Excellent & 0.83 & {$[0.16-0.96]$} & Excellent \\
\hline & Adduction & 0.89 & {$[0.52-0.97]$} & Excellent & 0.59 & {$[0.02-0.92]$} & Good \\
\hline & Internal rotation & 0.93 & {$[0.71-0.98]$} & Excellent & 0.45 & {$[0.03-0.89]$} & Good \\
\hline & External rotation & 0.97 & {$[0.92-0.99]$} & Excellent & 0.88 & {$[0.44-0.97]$} & Excellent \\
\hline & Flexion & 0.83 & {$[0.26-0.96]$} & Excellent & 0.72 & {$[0.39-0.94]$} & Very good \\
\hline Elbow & Extension & 0.81 & {$[0.17-0.96]$} & Excellent & 0.91 & {$[0.54-0.98]$} & Excellent \\
\hline & Flexion & 0.85 & {$[0.58-0.95]$} & Excellent & 0.30 & {$[0.05-0.73]$} & Reasonable \\
\hline & Extension & 0.84 & {$[0.30-0.96]$} & Excellent & 0.82 & {$[0.13-0.96]$} & Excellent \\
\hline
\end{tabular}


reference values for the general population. This study has as limitations the absence of measurements for a non-dominant limb, a fact justified by the extension of the assessment protocol of the 10 main muscle groups of $U L$, and by the fact that assessment of movements such as elbow pronation and supination is not included, as well as the wrist radial and ulnar deviations.

\section{CONCLUSIONS}

Reliability of assessing muscle strength of UL with Hand-Held dynamometry is excellent for test and retest, as well as for inter-examiner measurement in an assessment protocol in supine position, with previously trained examiners. Comparing fixed and non-fixed methods to assess Hand-Held dynamometry demonstrated superiority of the non-fixed method for inter- and intra-examiner reliability. Only for elbow extensors and external shoulder rotators Hand-Held dynamometry seems to show equivalence between the two methods.

All authors declare no potential conflict of interest related to this article

AUTHORS' CONTRIBUTIONS: Each author made significant individual contributions to this manuscript. BRVNJ: data collection, writing, statistical analysis, intellectual concept; MPSM: data collection, writing, revision; KRBSM: data collection, writing, revision; MGN: intellectual concept, elaboration of the entire research project, revision.

\section{REFERENCES}

1. Cruz-Jentoft AJ, Bahat G, Bauer J, Boirie Y, Bruyére O, Cederholm T, et al. Sarcopenia: revised European consensus on definition and diagnosis. Age Ageing. 2019;48(1):16-31.

2. Fontes AP, Fernandes AA, Botelho MA. Funcionalidade e incapacidade: aspectos conceptuais, estruturais e de aplicação da Classificação Internacional de Funcionalidade, Incapacidade e Saúde (CIF). Rev Port Saúde Pública. 2010;28(2):171-8.

3. Porto JM, Nakaishi APM, Cangussu-Oliveira LM, Freire RC, Spilla SB, de Abreu DCC. Relationship between grip strength and global muscle strength in community-dwelling older people. Arch Gerontol Geriatr. 2019;82:273-8.

4. Kemmler W, von Stengel S, Schoene D. Longitudinal Changes in Muscle Mass and Function in Older Men at Increased Risk for Sarcopenia - The FrOST-Study. J Frailty Aging. 2019;8(2):57-61.

5. Schrama PP, Stenneberg MS, Lucas C, van Trijffel E. Intraexaminer reliability of hand-held dynamometry in the upper extremity: a systematic review. Arch Phys Med Rehabil. 2014;95(12):2444-69.

6. Polat S, Öğüt E, Göker P, Bozkır MG, Yücel AH. Reference values for hand muscle strength evaluation methods in healthy young adults. J Back Musculoskelet Rehabil. 2019;32(6):921-9.

7. Meyer C, Corten K, Wesseling M, Peers K, Simon JP, Jonkers I, et al. Test-Retest Reliability of Innovated Strength Tests for Hip Muscles. PLoS One. 2013;8(11):e81149.

8. Edwards RHT, McDonnell M. Hand-held dynamometer for evaluating voluntary muscle function. The Lancet. 1974;304(7883):757-8.

9. Siegel KL, Hicks JE, Koziol DR, Gerber LH, Rider LG. Walking ability and its relationship to lowerextremity muscle strength in children with idiopathic inflammatory myopathies. Arch Phys Med Rehabil. 2004;85(5):767-71.

10. Merlini L, Bertini E, Minetti C, Mongini T, Morando L, Angelini C, et al. Motor function-muscle strength relationship in spinal muscular atrophy. Muscle Nerve. 2004;29(4):548-52.

11. Mentiplay BF, Perraton LG, Bower KJ, Adair B, Pua Y-H, Williams GP, et al. Assessment of Lower Limb Muscle Strength and Power Using Hand-Held and Fixed Dynamometry: A Reliability and Validity Study. PLOS ONE. 2015;10(10):e0140822.

12. Martin HJ, Yule V, Sydall HE, Dennison EM, Cooper C, Aihie Sayer A. Is Hand- Held Dynamometry Usefu for the Measurement of Quadriceps Strength in Older People? A Comparison with the Gold Standard Biodex Dynamometry. Gerontology. 2006;52(3):154-9.

13. Clavet $H$, Hébert PC, Fergusson D, Doucette $S$, Trudel G. Joint contracture following prolonged stay in the intensive care unit. CMAJ. 2008;178(6):691-7.
14. Fieseler G, Molitor T, Irlenbusch L, Delank KS, Laudner KG, Hermassi S, et al. Intrarater reliability of goniometry and hand held dynamometry for shoulder and elbow examinations in female team handball athl etes and asymptomatic volunteers. Arch Orthop Trauma Surg. 2015;135(12):1719-26.

15. Davis PR, Mckay MJ, Baldwin JN, Burns J, Pareyson D, Rose KJ. Repeatability, consistency, and acurracy of hand-held dynamometry with and without fication fot measuring ankle plantarflexion strength in healthy adolescentes and adults. Muscle Nerve. 2017;56(5):896-900.

16. Almeida GPL, Albano TR, Melo AKP. Hand-held dynamometer identifies asymmetries in torque of the quadriceps muscle after anterior cruciate ligament reconstruction. Knee Surg Sports Traumato Arthrosc. 2019;27(8):2494-2501.

17. Hébert L, Maltais DB, Lepage C, Saulnier J, Crête M. Hand- Held Dynamometry Isometric Torque Reference Values for Childrenand Adolescents. Pediatr Phys Ther. 2015;27(4):414-23.

18. Van der Ploeg, Fidler V, Oosterhuis HJ. Hand-held myometry: reference values. J Neurol Neurosurg Psychiatry. 1991;54(3):244-7

19. Nepomuceno Junior BRV and Gomes Neto M. Avaliação da força muscular dos membros superiores através do dinametro hand held: estudo piloto. Rev Ciênc Méd Biol. 2020;19(2):325-30.

20. RheaultW, Beal JL, Kubik KR, NowakTA, Shepley JA. Intertester reliability of the Hand-held dynamometer for wrist flexion and extension. Arch Phys Med Rehabil. 1989;70(13):907-10.

21. Cadogan A, Laslett M, Hing W, McNair P, Williams M. Reliability of a new hand-held dynamometer in measuring shoulder range of motion and strength. Man Ther. 2011;16(1):97-101.

22. Saccol MG, dos Santos G, Oliano HJ. Inter- and intra-examiner reliability of the strength of shoulder rotators in different positions using isometric dynamometry. Fisioter Pesqui. 2017;24(4):406-11.

23. Weir JP. Quantifying test-retest reliability using the intraclass correlation coefficient and the SEM. Strength Cond Res. 2005;19(1):231-40.

24. Awatani T, Morikita I, Shinohara J, Mori S, Narial M, Tatsumi Y, et al. Intra- and inter-rater reliability of isometric shoulder extensor and internal rotator strength measurements performed using a hand-held dynamometer. J Phys Ther Sci. 2016;28(11):3054-9.

25. Dowman L, McDonald CF, Hill CJ, Lee A, Barker K, Boote C, et al. Reliability of the hand held dynamometer in measuring muscle strength in people with interstitial lung disease. Physiotherapy. 2016;102(3):249-55. 